\title{
Climate warming enhances polar cod recruitment, at least transiently
}

\author{
Caroline Bouchard ${ }^{\mathrm{a}, *, 2}$, Maxime Geoffroy ${ }^{\mathrm{a}, \mathrm{b}, 1,2}$, Mathieu LeBlanc $^{\mathrm{a}, 2}$, Andrew Majewski $^{\mathrm{c}}$, \\ Stéphane Gauthier ${ }^{\mathrm{d}}$, Wojciech Walkusz ${ }^{\mathrm{c}}$, James D. Reist ${ }^{\mathrm{c}}$, Louis Fortier ${ }^{\mathrm{a}}$ \\ a Québec-Océan, Université Laval, Department of Biology, Québec, QC G1V 0A6, Canada \\ ${ }^{\mathrm{b}}$ UiT The Arctic University of Norway, Department of Arctic and Marine Biology, 9037 Tromsø, Norway \\ ${ }^{\mathrm{c}}$ Fisheries and Oceans Canada, Freshwater Institute, Winnipeg, MB R3T 2N6, Canada \\ ${ }^{\mathrm{d}}$ Fisheries and Oceans Canada, Institute of Ocean Sciences, Sidney, BC V8L 4B2, Canada
}

\section{A R T I C L E I N F O}

\section{Article history:}

Received 22 March 2017

Received in revised form 16 June 2017

Accepted 24 June 2017

Available online 27 June 2017

\begin{abstract}
A B S T R A C T
Polar cod (Boreogadus saida) is the dominant forage fish in Arctic seas and the main prey of the ringed seal (Pusa hispida), the beluga (Delphinapterus leucas) and several seabird species. Changes in the abundance of polar cod will have cascading effects on arctic marine ecosystems. We tested the hypothesis that an earlier sea ice breakup and warmer sea surface temperatures (SST) in spring-summer result in the higher recruitment of juvenile polar cod in late summer. The density (number $\mathrm{m}^{-2}$ ) and biomass $\left(\mathrm{mg} \mathrm{m}^{-2}\right.$ ) of age-0 polar cod in August and September, estimated by hydroacoustics over 9 years in 9 areas of the Canadian Arctic, were negatively correlated to ice breakup week and positively correlated to SST. The timing of the ice breakup was the main determinant of recruitment, with mean juvenile biomass in September up to 11 times greater for early breakup (late May) than for late breakup (early September). Early ice breakup in spring increased juvenile biomass in August and September by allowing the survival of larvae hatched in winter and spring. Since 1979, ice breakup has occurred earlier by as much as 9.3 days per decade in some areas. We thus forecast a transient increase in polar cod biomass over the first part of the present century. Thereafter, the relaxation of extreme climatic conditions in Arctic seas should harbinger the replacement of the hyper-specialized polar cod by subarctic and boreal forage fish.
\end{abstract}

Crown Copyright @ 2017 Published by Elsevier Ltd. All rights reserved.

\section{Introduction}

Sea surface temperature (SST) has increased in most Arctic seas over the last century, with warming intensifying since 1995 (Steele et al., 2008). Arctic sea ice extent (Stroeve et al., 2012) and volume (Laxon et al., 2013) have declined during all seasons, and ice breakup has occurred progressively earlier (Stroeve et al., 2012). Among the biological consequences of climate warming, an increase in primary production (Tremblay and Gagnon, 2009), a shift towards smaller phytoplankton and zooplankton species (Hop et al., 2006; Li et al., 2009), the development of an Atlantictype autumn bloom (Ardyna et al., 2014), perturbations of the phenology of key species (Ji et al., 2013; Søreide et al., 2010), and the poleward expansion of boreal species (e.g. Falardeau et al., in press;

\footnotetext{
* Corresponding author at: Greenland Institute of Natural Resources, Greenland Climate Research Centre, 3900 Nuuk, Greenland.

E-mail address: cabo@natur.gl (C. Bouchard).

1 Present address: Centre for Fisheries Ecosystems Research, Marine Institute of Memorial University of Newfoundland, St. John's, NL A1C 5R3, Canada.

2 These authors contributed equally to the manuscript and the order was determined randomly.
}

Fossheim et al., 2015; Lenoir et al., 2011; Perry et al., 2005; Renaud et al., 2012) already impact arctic marine ecosystems.

The Arctic pelagic food web is relatively simple and dominated by a few species (Welch et al., 1992). The intermediate trophic level between zooplankton and top predators is occupied almost exclusively by the small polar cod Boreogadus saida, a fish with large biomasses and high trophic connectivity (Fortier et al., 2015; Kortsch et al., 2015). Changes in its abundance in response to the ongoing warming of Arctic seas could have profound effects on arctic marine ecosystems and the services they provide to society, especially Inuit communities (Fortier et al., 2015; Tynan and DeMaster, 1997).

In teleosts, interannual fluctuations in the survival of the eggs, larvae, and early juveniles determine the number of fish that recruit to the adult population in a given year (Browman, 2014; Houde, 2008). Hence, any factor influencing early survival may affect adult population size. The hatching season of polar cod extends from January to July, and higher temperatures have been linked to enhanced growth and survival of the larval stages (Bouchard and Fortier, 2008, 2011; Fortier et al., 2006). A large pre-winter size has been suggested as an important survival advantage (Bouchard and Fortier, 2008, 2011). Summer hatchers 
experience higher temperatures and more abundant food that result in faster growth. However, winter hatchers benefit from a longer growing season and reach pre-winter weights 100-150 times those of summer hatchers (Bouchard and Fortier, 2011). An early sea ice breakup should favour the survival of early hatchers and the recruitment of large juvenile polar cod in late summer. The density and biomass of juveniles (age-0) are predictors of fish recruitment (e.g. Laurel et al., 2016a; Sogard, 1997). In polar cod, these variables can be assessed using hydroacoustics validated by ichthyoplankton net collections (Geoffroy et al., 2016).

In this study, we first test the hypothesis that an early sea ice breakup and the associated high spring-summer SST promote the recruitment of juvenile polar cod. We then explore whether higher recruitment is primarily caused by higher survival of early-hatched larvae or by faster growth over the summer. Hydroacoustic estimates of the density and biomass of age- 0 polar cod from August to October validated by net sampling were correlated to satellitebased estimates of sea ice breakup dates and mean SST in springsummer. Juvenile density and biomass in late summer-early fall were calculated in different years over a 9-year period for 9 sea ice areas of the Canadian Arctic as defined by the Canadian Ice Service. The hatch date of age- 0 polar cod collected by nets was determined by otolith analyses. Based on trends in ice breakup date since 1979 , we project the pre-winter size and biomass of age- 0 polar cod in August 2050 and 2100.

\section{Materials and methods}

\subsection{Study area}

From 2005 to 2015, the research icebreaker CCGS Amundsen and the trawler F/V Frosti conducted acoustic-trawl surveys in Canadian Arctic seas between early August and late October (Table 1, Fig. 1). Conductivity-Temperature-Depth (CTD) profiles from the Amundsen (SBE-911 plus ${ }^{\circledR}$ ) and the Frosti (SBE-25 and SBE-19 plusV2 ${ }^{\circledR}$ ) were used to determine sound speed in water $c_{\mathrm{w}}$ (Mackenzie, 1981) and the frequency-dependent coefficient of sound absorption $\alpha_{a}$ (Francois and Garrison, 1982) for acoustic calculations.

\subsection{Remote sensing data}

The annual date of the ice breakup since 1979 was determined for 9 areas defined by the Canadian Ice Service (www.ec.gc.ca/ glaces-ice). These included M'Clintock Channel, Peel Sound, Larsen-Victoria Sounds and Coronation-Maud in the Kitikmeot; West Baffin Bay and North-West Baffin Bay in Baffin Bay; and Mackenzie Shelf, Amundsen Gulf and Amundsen Gulf Mouth in the Beaufort Sea (Fig. 1). For each area and year, the week during which ice concentration fell below $50 \%$ was used as the date of the ice breakup (Scott and Marshall, 2010). In M'Clintock Channel, the ice cover remained $>50 \%$ through the summer in 21 years. In these cases, week 41 (latest week of ice breakup in this area +1) was used. For each area and year, mean SST from 1 May to 31 July (corresponding to the main growth season of larval polar cod) was calculated using Level 3 daytime $11 \mu \mathrm{m}$ wave band Aqua MODIS remote sensing data at a $4 \mathrm{~km}^{2}$ resolution (https://oceancolor. gsfc.nasa.gov/cgi/l3).

\subsection{Ichthyoplankton sampling}

Ichthyoplankton nets were deployed to identify the juvenile fish assemblage and validate the acoustic signals from the epipelagic layer (Fig. 1). A double square net bearing two square-conical nets ( $1-\mathrm{m}^{2}$ aperture, $500-\mu \mathrm{m}$ and $750-\mu \mathrm{m}$ meshes) and a rectangular midwater trawl (8- $\mathrm{m}^{2}$ aperture, $1600-\mu \mathrm{m}$ mesh) were deployed from the Amundsen. A bongo net (0.25- $\mathrm{m}^{2}$ aperture, $500-\mu \mathrm{m}$ mesh) and an Enzenhofer and Hume midwater trawl (9- $\mathrm{m}^{2}$ aperture; $0.63-\mathrm{cm}$ mesh) were used on the Frosti. Ichthyoplankton nets were cast from the surface to depths varying from 10 to $\leq 100 \mathrm{~m}$, corresponding to the epipelagic layer where age-0 polar cod typically make up $>90 \%$ of the fish assemblage (Geoffroy et al., 2016). The standard length (SL) of up to 50 gadids (i.e. possibly both polar and ice cods - see below) per station was measured fresh before preservation in 95\% ethanol. For each year, a monthly mean SL was calculated for each area. Values from the Amundsen and the Frosti for a given year and area were pooled.

\subsection{Otolith analysis}

The lapillar otoliths of a stratified subset of 962 polar cod from all areas and years were extracted and polished (see Bouchard and Fortier, 2008 for further details). Daily growth rings were enumerated under a microscope coupled to an image analyser to determine the age and hatch date (HD: date of capture - age at capture) of each fish. Based on the size of the otolith nucleus (Bouchard et al., 2013), 34 Arctogadus glacialis were detected and discarded from the analysis. To compare SL at age between years and areas, SL on 6 August (the earliest date a polar cod was captured over the 2005-2015 period) was back-calculated from increment width using the biological intercept method (Campana and Jones, 1992).

\subsection{Hydroacoustics}

On both the Amundsen and the Frosti, hydroacoustic data were continuously recorded with a Simrad EK60 ${ }^{\circledR}$ split-beam echosounder with hull-mounted transducers at $38 \mathrm{kHz}$ and $120 \mathrm{kHz}$ (both with nominal beam angle of $7^{\circ}$ ). The ping rate varied from $\sim 1$ to $2 \mathrm{~s}$ depending on maximum depth, and pulse duration was set to $1024 \mu \mathrm{s}$. Power was $2 \mathrm{~kW}$ at $38 \mathrm{kHz}$ and $500 \mathrm{~W}$ (2006-2011) or

Table 1

Annual ichthyoplankton net and hydroacoustic sampling periods (date range) for each region. No hydroacoustic data were recorded in 2005.

\begin{tabular}{|c|c|c|c|c|c|c|c|c|c|}
\hline \multirow[t]{2}{*}{ Year } & \multicolumn{3}{|c|}{ Beaufort Sea } & \multicolumn{3}{|c|}{ Kitikmeot } & \multicolumn{3}{|c|}{ Baffin Bay } \\
\hline & Aug & Sep & Oct & Aug & Sep & Oct & Aug & Sep & Oct \\
\hline 2005 & & & & $27-30$ & & & $16-22$ & & \\
\hline 2006 & & & & & $23-27$ & & & $6-20$ & \\
\hline 2007 & & & & & & $11-13$ & & & $1-4$ \\
\hline 2008 & & & & & & & & $9-23$ & \\
\hline 2010 & $14-31$ & & $1-8$ & $8-14$ & & & & & \\
\hline 2011 & & $1-31$ & $1-4$ & $7-12$ & & $3-8$ & & & $15-22$ \\
\hline 2012 & $6-31$ & & & & & & & & \\
\hline 2013 & $1-31$ & & & & & & $9-29$ & & \\
\hline 2014 & $2-31$ & $1-25$ & & $10-16$ & & & $1-7$ & & \\
\hline 2015 & & & & $15-20$ & $20-23$ & & $4-12$ & & $5-19$ \\
\hline
\end{tabular}




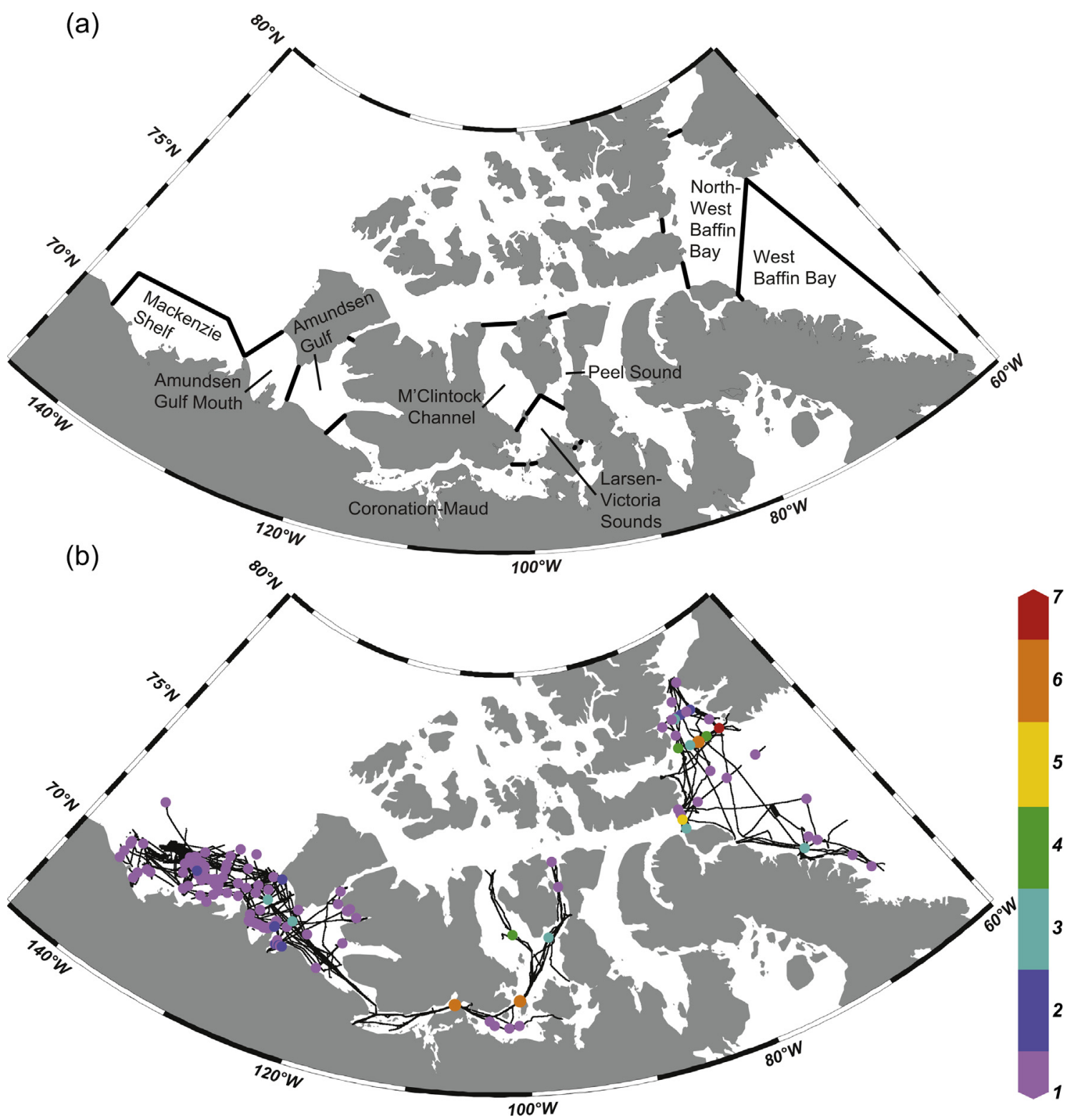

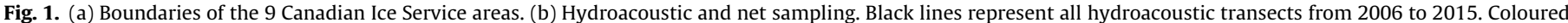

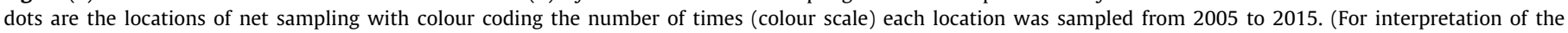
references to colour in this figure legend, the reader is referred to the web version of this article.)

$250 \mathrm{~W}(2012-2015)$ at $120 \mathrm{kHz}$. Transducers were calibrated annually using the standard sphere method (Demer et al., 2015). The echograms were edited with Echoview ${ }^{\circledR}$ (versions 5 and 6) to correct for bottom detection and to remove signals distorted by ice breaking noise, the lowering of scientific instruments, and interferences from other acoustic sources. Time-varied gain (TVG) profiles were added based on the mean $c_{\mathrm{w}}$ (sound speed) and $\alpha_{a}$ (frequency-dependent coefficient of sound absorption) calculated from the closest CTD cast. A time-varied threshold (TVT $=20 \log \mathrm{R}+2 \alpha_{a} \mathrm{R}-140$, where $\mathrm{R}$ is the range from the transducer) was also added to the volume backscattering strength echograms to compensate for noise amplification at depth by the TVG (e.g. Geoffroy et al., 2016). The difference in mean volume backscattering strength ( $\triangle \mathrm{MVBS})$ at 38 and $120 \mathrm{kHz}$ between corresponding echo-integration cells 0.25 nautical mile long by $3 \mathrm{~m}$ deep allowed discriminating pelagic fish from zooplankton $\left(\triangle \mathrm{MVBS}_{120-38}\right.$ ranging from -10 to $5 \mathrm{~dB}$ re $1 \mathrm{~m}^{2} \mathrm{~m}^{-3}$, Benoit et al., 2014; Geoffroy et al., 2016). Outliers and echo-integration cells with a volume backscattering strength $S_{v}>-40 \mathrm{~dB}$ re $1 \mathrm{~m}^{2}$ - $\mathrm{m}^{-3}$ were also discarded to avoid the inclusion of remaining bottom and artefact noise signals.

For each area and year, the monthly mean polar cod SL measured from net collections was transformed into mean target strength $\left(\mathrm{TS}_{\mathrm{N}}=14.33 \log _{10}\right.$ (mean $\left.\mathrm{SL}\right)-65.13$; Geoffroy et al., 2016). $\mathrm{TS}_{\mathrm{N}}$ (dB re $1 \mathrm{~m}^{2}$ ) and the nautical area backscattering coefficient (NASC, in $\mathrm{m}^{2}$ nautical mile $\mathrm{e}^{-2}$ ) were then used to estimate the density of polar cod (Parker-Stetter et al., 2009) integrated between $13.5 \mathrm{~m}$ (shallowest effective sampling depth of the transducers due to their position on the Amundsen's hull and exclusion of near-field effect) and $100 \mathrm{~m}$ depth (or $1 \mathrm{~m}$ above the bottom in areas $<100 \mathrm{~m}$ deep). We assumed that the SL of juvenile fish captured by nets from the surface to $100 \mathrm{~m}$ was representative of the fish producing the acoustic signals in the 13.5-100 $\mathrm{m}$ depth layer. Integrated density ( $D$ in number $\mathrm{m}^{-2}$ ) was then transformed into biomass ( $\mathrm{B}$ in $\mathrm{mg} \mathrm{m}^{-2}$ ) based on the monthly mean weight estimated from net samples (Benoit et al., 2008; Simmonds and MacLennan, 2005) and the weight-length regression for polar cod (Weight $=0.0055 \mathrm{SL}^{3.19}$; Geoffroy et al., 2016). 
The fine-scale vertical distribution of young polar cod is poorly documented, but $59 \%$ of larvae and juveniles 5-35 mm captured from early June to early August by a multinet sampler between the surface and $140 \mathrm{~m}$ were found in the top $10 \mathrm{~m}$ of the water column (Bouchard et al., 2016). Hence, by excluding the top $13.5 \mathrm{~m}$ of the water column, our acoustical estimates of age- 0 polar cod abundance and biomass are certainly underestimates. However, the bias is assumed constant across years and areas. Hereafter, the $13.5-100 \mathrm{~m}$ depth interval is defined as the epipelagic layer.

\subsection{Statistics}

Correlations between environmental variables and the density or biomass of epipelagic age-0 polar cod were tested with the non-parametric Spearman rank correlation coefficient. Linear regressions of ice breakup date on year were calculated to predict breakup date and juvenile biomass in 2050 and 2100. A two-way ANOVA was performed to test the effect of hatch date and spring-summer SST on SL on 6 August. All statistical analyses were conducted with $\mathrm{R}$ version 1.0.136.

\section{Results}

3.1. Ice breakup, sea surface temperatures, and the survival of age-0 polar cod

Over the period 1979-2016, ice breakup week occurred progressively earlier in all areas (Spearman rank correlation, $P \leq 0.05)$. The linear regression of breakup week on year was statistically significant for all areas except North-West Baffin Bay and Amundsen Gulf (Table 2). The rate of hastening of the breakup varied from $2.8 \mathrm{ddecade}^{-1}$ in the Coronation-Maud area to $9.3 \mathrm{~d} \mathrm{decade}^{-1}$ in the Mackenzie Shelf area (Table 2).

From 2005 to 2015, mean SST in spring-summer (1 May to 31 July) increased significantly (Spearman rank correlation, $P \leq 0.0001$ ) with an earlier ice breakup (Fig. 2). For all areas, mean SST reached $\sim 2-5{ }^{\circ} \mathrm{C}$ when ice breakup occurred before week 25 (19-25 June) and remained around $0{ }^{\circ} \mathrm{C}$ when ice broke up after week 31 (end of July).

The density (number $\mathrm{m}^{-2}$ ) of age- 0 polar cod in the epipelagic layer (13.5-100 m) in August and September decreased exponentially with later breakup week and increased exponentially with increasing spring-summer SST (Fig. 3; Spearman rank correlation, $P=0.04$ ). No significant correlation was found in October (Fig. 3).

The standard length on 6 August of age- 0 polar cod sampled by net increased exponentially with earlier ice breakup and warmer SST (Fig. 4a and b). Mean SL on 6 August ranged from $7.6 \mathrm{~mm}$ in Larsen-Victoria Sounds in 2005 to $30.7 \mathrm{~mm}$ in Mackenzie Shelf in 2014 , corresponding respectively to $2.3 \mathrm{mg}$ and $197 \mathrm{mg}$ wet weight, an 85-fold difference.

SL on 6 August was strongly influenced by hatch date (HD; Fig. 4c) and, to a lesser extent, by spring-summer SST (two-way

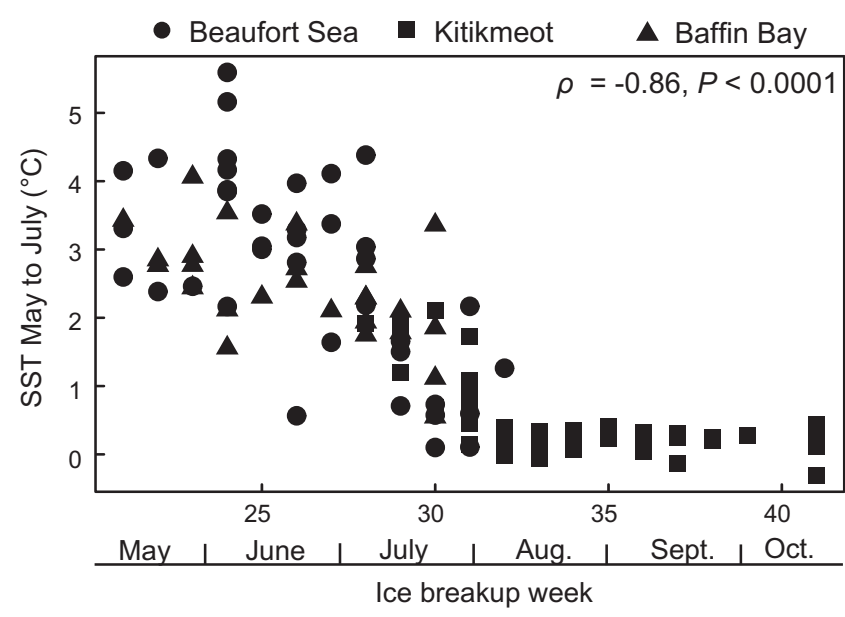

Fig. 2. Mean SST in spring-summer (from 1 May to 31 July) in relation to ice breakup week (IBW) from 2005 to 2015 for all areas in the Beaufort Sea, the Kitikmeot, and Baffin Bay. $\rho$ is the Spearman rank correlation coefficient.

ANOVA, $\left.\mathrm{F}_{\mathrm{HD}}=6126, P<0.0001 ; \mathrm{F}_{\mathrm{SST}}=1156, P<0.0001\right)$. There was no significant interaction between HD and SST $(P=0.73)$.

The biomass of age- 0 polar cod in the epipelagic layer in August and September increased exponentially with earlier breakup and increasing spring-summer SST (Fig. 5). Ice breakup week explained $63 \%$ of biomass variations in August and 65\% in September (linear regressions, $P \leq 0.002$ ). Epipelagic juvenile biomass in September obtained from the linear regression, ranged from $38 \mathrm{mg} \mathrm{m}^{-2}$ for the latest sea ice breakup observed on week 36 (early September) to $420 \mathrm{mg} \mathrm{m}^{-2}$ for the earliest observed breakup on week 21 (mid May), an 11-fold difference. There was no indication that the relationships between biomass and ice breakup week or SST differed among the Beaufort Sea, Kitikmeot, and Baffin Bay regions (Fig. 5). No significant correlation was found in October.

\subsection{Forecasting age-0 polar cod biomass in 2050 and 2100}

The regressions of ice breakup week on years for different areas of the Canadian Arctic (Table 2) predict that breakup will occur 15 weeks earlier than nowadays in 2050 and 4-11 weeks earlier in 2100 (Table 3). Depending on the area, the projected average standard length (weight) of epipelagic juveniles on 6 August will be $15-30 \mathrm{~mm}(19-176 \mathrm{mg})$ in 2050 and $20-42 \mathrm{~mm}(49-519 \mathrm{mg})$ in 2100. By comparison, observed mean SL (weight) on 6 August from 2005 to 2015 varied from 11 to $25 \mathrm{~mm}$ (7-102 mg) among all areas.

According to our results, earlier ice breakup will also increase the biomass of age-0 polar cod in the epipelagic layer in late summer. Depending on the area, an earlier ice breakup would increase the biomass of epipelagic juveniles in August by a median value of 2.7 folds (0.9-18) by 2050 and 9.7 folds (3-131) by 2100 (Table 3 ).

Table 2

Regression of ice breakup week (IBW) on year (Y) for 1979-2016 ( $n=38$ years) by sea ice area, and corresponding hastening of the breakup in days per decade.

\begin{tabular}{|c|c|c|c|c|}
\hline Area & Regression & $r^{2}$ & $P$ & Days per decade \\
\hline W Baffin Bay & $I B W=-0.0742 Y+177.77$ & 0.35 & $<0.0001$ & 5.2 \\
\hline NW Baffin Bay & $I B W=-0.0551 Y+134.58$ & 0.08 & 0.08 & 3.9 \\
\hline M'Clintock Channel & $I B W=-0.1265 Y+291.40$ & 0.23 & 0.002 & 8.9 \\
\hline Larsen-Victoria Sounds & $I B W=-0.1010 Y+236.92$ & 0.25 & 0.001 & 7.1 \\
\hline Peel Sound & $I B W=-0.0646 Y+162.75$ & 0.10 & 0.05 & 4.5 \\
\hline Coronation-Maud & $I B W=-0.0407 Y+111.73$ & 0.17 & 0.01 & 2.8 \\
\hline Amundsen Gulf & $I B W=-0.0743 Y+176.28$ & 0.05 & 0.16 & 5.2 \\
\hline Amundsen Gulf Mouth & $I B W=-0.1131 Y+252.21$ & 0.14 & 0.02 & 7.9 \\
\hline Mackenzie Shelf & $I B W=-0.1327 Y+293.47$ & 0.14 & 0.02 & 9.3 \\
\hline
\end{tabular}




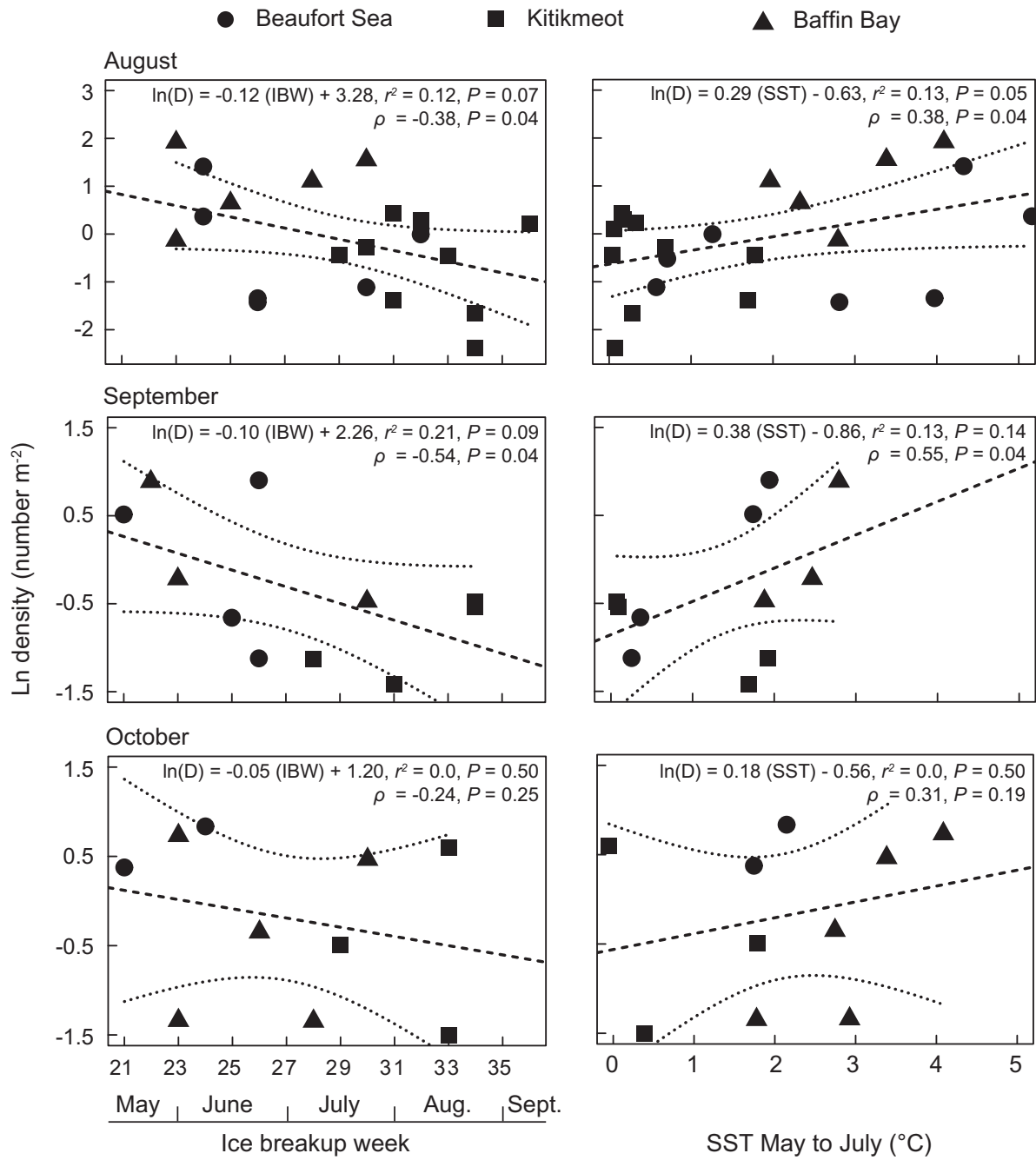

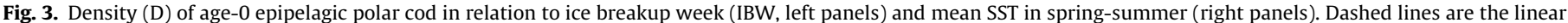
regressions and dotted lines the $95 \%$ confidence intervals. $\rho$ is the Spearman rank correlation.

(a)

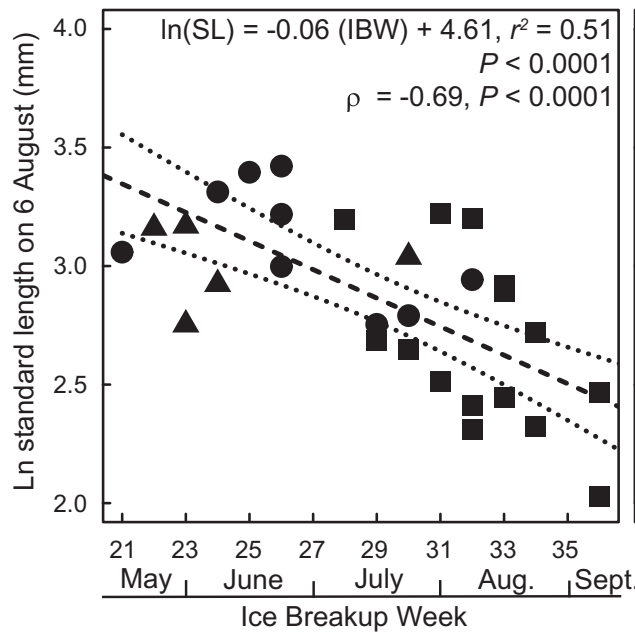

(b)

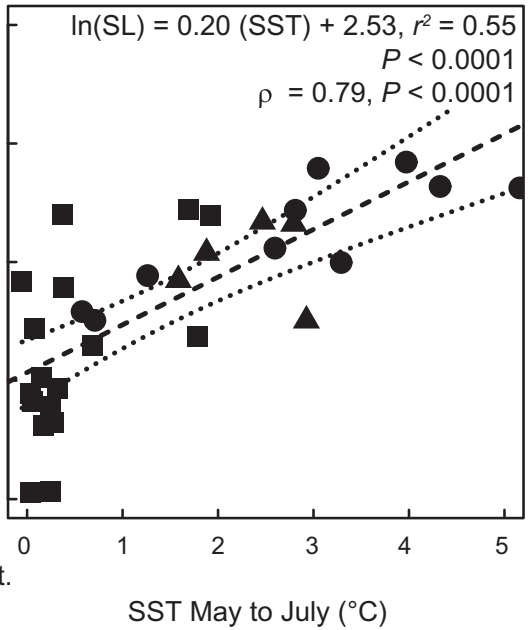

(c)

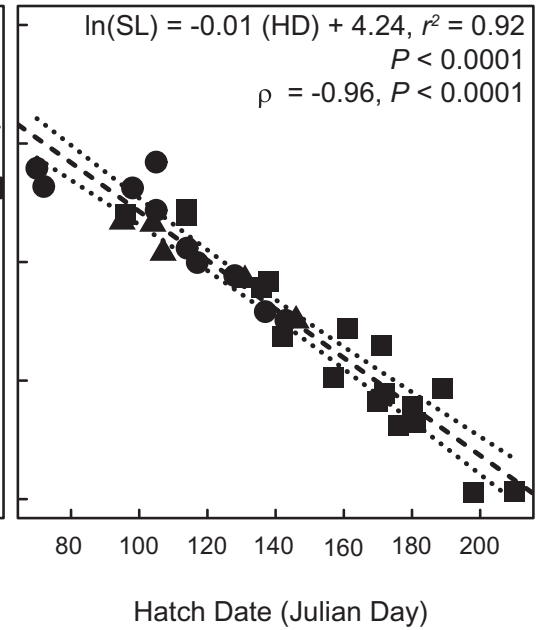

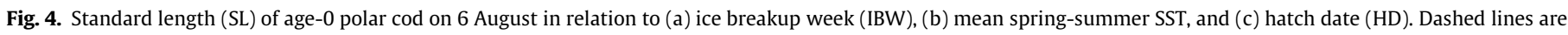
the linear regressions and dotted lines the $95 \%$ confidence intervals. $\rho$ is the Spearman rank correlation. 


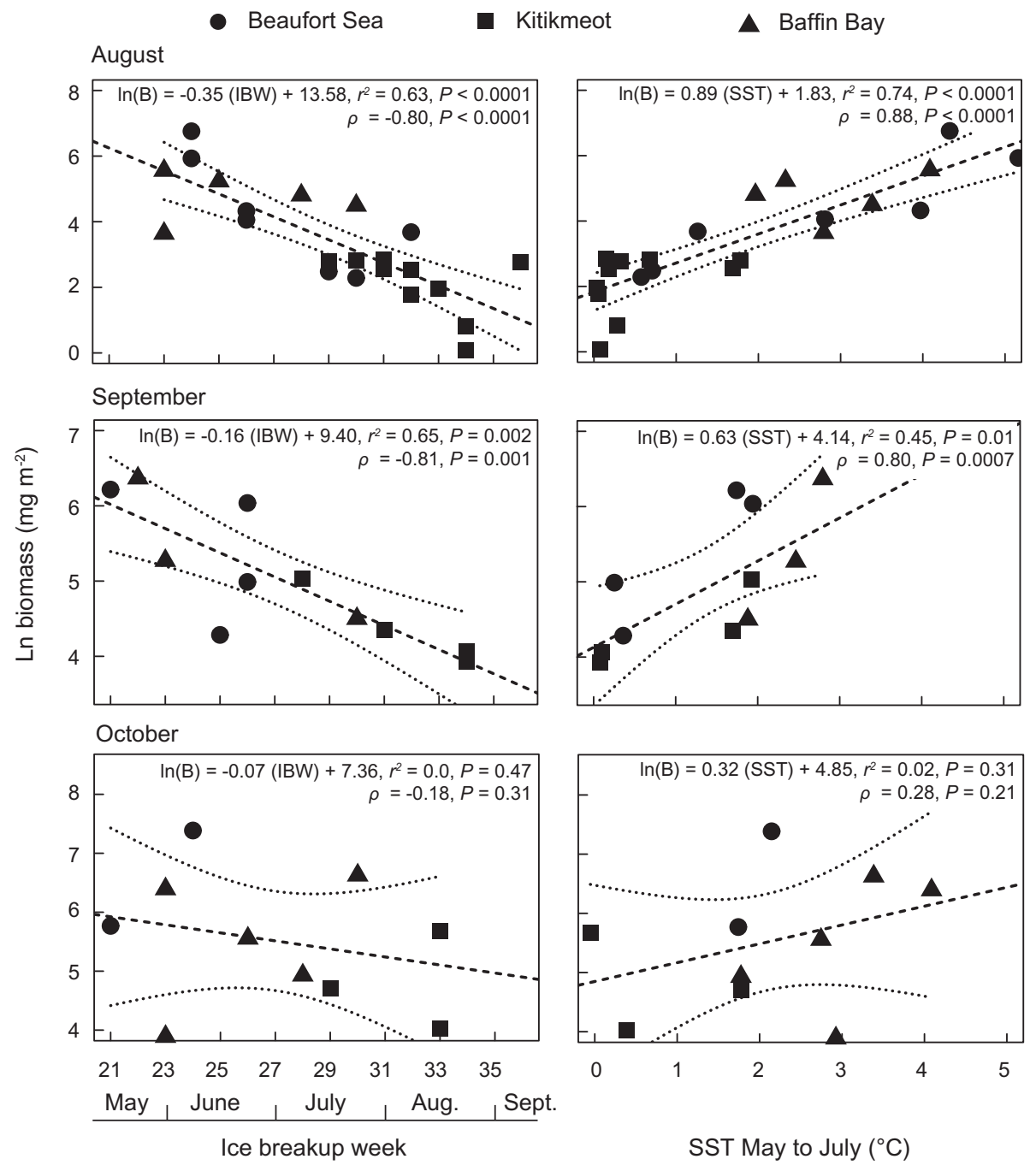

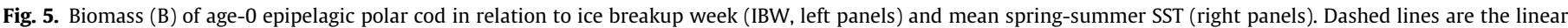
regressions and dotted lines the $95 \%$ confidence intervals. $\rho$ is the Spearman rank correlation.

Table 3

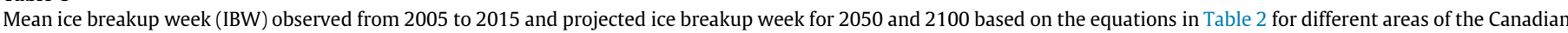

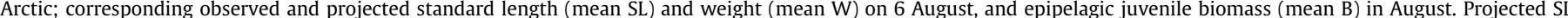

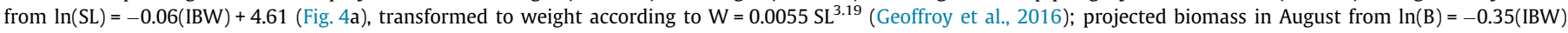
+13.58 (Fig. 5)

\begin{tabular}{|c|c|c|c|c|c|c|c|c|c|c|c|c|}
\hline \multirow[t]{2}{*}{ Area } & \multicolumn{3}{|c|}{ Week of ice breakup } & \multicolumn{3}{|c|}{ SL on 6 August (mm) } & \multicolumn{3}{|c|}{ Weight on 6 August (mg) } & \multicolumn{3}{|c|}{ Biomass in August $\left(\mathrm{mg} \mathrm{m}^{-2}\right)$} \\
\hline & 2005-2015 & 2050 & 2100 & 2005-2015 & 2050 & 2100 & 2005-2015 & 2050 & 2100 & 2005-2015 & 2050 & 2100 \\
\hline W Baffin Bay & 28 & 26 & 22 & 21.1 & 21.6 & 26.9 & 59.4 & 63.7 & 129.5 & 112 & 99 & 363 \\
\hline NW Baffin Bay & 23 & 22 & 19 & 20.6 & 27.5 & 32.4 & 55.4 & 138.0 & 233.7 & 172 & 408 & 1068 \\
\hline M'Clintock Channel & 36 & 32 & 26 & 15.8 & 14.7 & 21.4 & 23.8 & 18.6 & 62.6 & - & 10 & 96 \\
\hline Larsen-Victoria Sounds & 34 & 30 & 25 & 10.6 & 16.7 & 22.7 & 6.7 & 28.5 & 74.8 & 5 & 23 & 133 \\
\hline Peel Sound & 33 & 30 & 27 & 11.1 & 16.3 & 19.8 & 7.7 & 26.1 & 48.5 & 12 & 19 & 60 \\
\hline Coronation-Maud & 30 & 28 & 26 & 20.6 & 18.4 & 20.8 & 54.8 & 38.4 & 56.8 & 13 & 39 & 80 \\
\hline Amundsen Gulf & 27 & 24 & 20 & 23.1 & 23.9 & 29.8 & 79.0 & 88.1 & 179.3 & 10 & 180 & 659 \\
\hline Amundsen Gulf Mouth & 25 & 20 & 15 & 20.7 & 29.6 & 41.6 & 55.8 & 176.1 & 519.1 & 35 & 636 & 4595 \\
\hline Mackenzie Shelf & 26 & 21 & 15 & 25.0 & 27.8 & 41.4 & 101.6 & 142.8 & 509.2 & 338 & 434 & 4437 \\
\hline
\end{tabular}

\section{Discussion}

\subsection{The mechanism linking polar cod recruitment to ice breakup timing}

A central paradigm of fisheries science is that the size of an annual cohort of fish (the strength of a year class) is determined by survival during the early larval life from hatching to metamor- phosis into juvenile (e.g. Houde, 2008). The match/mismatch hypothesis proposes that early growth and survival depend on the synchronized development of the larvae and their plankton food (Cushing and Horwood, 1994). Somewhat at odds with this hypothesis, the hatching season of polar cod extends from as early as January to the first week of July, with most larvae hatching under the ice in April and May when light, temperature, and prey availability are low - an apparent evolutionary aberration 
(Bouchard and Fortier, 2008, 2011; Fortier et al., 2006). It has been suggested that the selection force driving some polar cod to hatch under the ice in winter and early spring is the survival advantage provided by the large pre-winter size resulting from early hatching (Bouchard and Fortier, 2008, 2011; Fortier et al., 2006). In juvenile fish, a large size is associated with better winter survival through increased lipid content, predator avoidance, resistance to starvation, and physiological tolerance (e.g. Hunt et al., 2011; Sogard, 1997). In polar cod, the largest pre-winter sizes are achieved by larvae hatched in mid-winter in areas where river plumes provide a freshwater thermal refuge against sub-zero temperatures (Bouchard and Fortier, 2011). Hatching beyond mid-July, when temperature, light and food availability are at their maximum, is selected against because the pre-winter size achieved would be too small to ensure survival over the subsequent winter.

Our results are consistent with this notion that maximizing prewinter size rather than ensuring a match between larval growth and the maximum production of plankton food is the driving force behind the intriguing reproductive strategy of polar cod. Given an extended hatching season from January to early July, and notwithstanding suboptimal survival conditions in winter and spring relative to summer (Fortier et al., 2006), the survival of early hatchers is clearly enhanced in years and areas with an early ice breakup relative to late breakups, resulting in more abundant and heavier epipelagic juveniles in late summer (August and September). The resulting differences in size were spectacular, with mean weight on 6 August ranging from $2.3 \mathrm{mg}$ in Larsen-Victoria Sounds in 2005 (ice breakup in week 36 or early September) to $197 \mathrm{mg}$ on the Mackenzie Shelf in 2014 (ice breakup in week 26 or end of June). Hence, despite suboptimal conditions for the survival of first-feeding larvae in winter and spring relative to summer (Fortier et al., 2006), winter-spring hatching provides the potential for the population of juveniles to achieve large biomasses in the fall and, presumably, strong recruitment after the first winter. Given the central importance of polar cod in the pelagic food web of Arctic seas, poor juvenile recruitment in years of late breakup is expected to negatively impact polar cod predators. Consistent with this, poor reproduction in ringed seals has been associated with years of heavy ice conditions in the mid-1970s and mid-1980s in the Beaufort Sea (Stirling, 2002).

Among areas and years, an earlier ice breakup was correlated with warmer SST in spring-summer (Galbraith and Larouche, 2011; Wood et al., 2013). The early growth of polar cod is positively correlated to SST (Bouchard and Fortier, 2011) and survival is low at near-zero temperatures (Fortier et al., 2006). In the present study, the length achieved on 6 August was correlated to SST, but more strongly so to the mean hatch date of the fish collected in an area and a given year (Fig. $4 \mathrm{~b}$ and c). Hatch date explained 5.3 times more variability in length on 6 August than did SST (ratio of the F statistics in the two-way ANOVA). Hence, early ice breakup favours a large pre-winter size primarily by allowing the survival of early hatchers and to a lesser extent by providing warmer temperatures for growth over the summer. Polar cod larvae and epipelagic juveniles are visual predators that feed primarily on calanoid copepod nauplii (Bouchard et al., 2016; Michaud et al., 1996). We suspect that, in addition to higher SST, advanced blooms of ice algae and phytoplankton (e.g. Kahru et al., 2011), the associated hastening of the production of copepod nauplii (e.g. Daase et al., 2013; Fortier et al., 1995; Ringuette et al., 2002), and a greater availability of light (e.g. Bouchard and Fortier, 2008; Ponton and Fortier, 1992; Varpe et al., 2015) were the proximal causes of the improved survival of early hatchers in years of early ice breakup.

Interestingly, the biomass of the epipelagic juveniles in August and September was more strongly correlated to ice breakup week or to spring-summer SST (Fig. 5) than were either density (Fig. 3) or size on 6 August (Fig. 4a and b). This suggests that biomass, which reflects both the number of fish surviving and the weight each survivor achieves, is the best integrator of the effect of the environment on the combined growth and survival of young epipelagic polar cod and on their ultimate recruitment.

The weakening in October of the slope of the relationship between biomass and ice breakup week or SST is not unexpected. Polar cod juveniles leave the epipelagic layer to descend to overwintering depths when they reach $35-55 \mathrm{~mm}$ in length (Benoit et al., 2014; Geoffroy et al., 2016). In years and areas with early ice breakup, juveniles will attain this threshold length early, and most will have left the epipelagic layer by October resulting in relatively low epipelagic biomasses in that month. In years and areas of late breakup, small size will delay migration to depth resulting in relatively high biomass in the top $100 \mathrm{~m}$ in October. Hence the importance of conducting surveys at the appropriate period (August and September in this case) when assessing the recruitment of juvenile polar cod.

\subsection{Polar cod and climate warming: a likely bust beyond the initial boom}

Age-2+ polar cod are mostly mesopelagic, forming dense aggregations in deep embayments and along the shelf slope (Benoit et al., 2008, 2014; Geoffroy et al., 2016, 2011). The epipelagic larvae and age- 0 juveniles develop in the top $100 \mathrm{~m}$ surface layer over the spring-summer (e.g. Bouchard and Fortier, 2011; Bouchard et al., 2016; Geoffroy et al., 2016). By early fall, age-0 juveniles descend to intermediate depths to join the deep adult population (Geoffroy et al., 2016) or colonize the ice pack as age-1 (David et al., 2016). Hence, it is primarily the epipelagic age-0 and the sympagic age-1 fish that are exposed to shifts in the sea ice and SST regimes induced by climate warming.

As in other Arctic regions (Stroeve et al., 2012), trends towards an earlier ice breakup have been observed over the period 19792016 in all nine areas of the Canadian Arctic studied here. Based on our results, this hastening of sea ice breakup forced by global warming will increase the biomass of age- 0 polar cod juveniles by a median value of 2.7 -fold (0.9-18) by 2050 and 9.7 -fold (3131 ) by 2100 across the different areas. Because interannual differences in mortality occur primarily during the larval stages, the density and biomass of juveniles at the end of their first growing season are valid proxies of gadid recruitment (Laurel et al., 2016a). Hence, the ongoing warming of the lower atmosphere will likely increase the abundance of polar cod in the Canadian High Arctic, at least as long as the observed relationships between ice breakup timing and juvenile biomass hold. Similar trends can be expected in other High Arctic regions, but not necessarily in subarctic zones of the distribution of the species, where any hastening of an already early ice breakup could be detrimental to the early survival of polar cod, and likely would favour competing boreal forage fish.

Our optimistic predictions for future polar cod recruitment assume that these relationships will persist through the century, despite the expected major shifts in sea ice and SST regimes. Statistical relationships linking fish recruitment to some environmental variable often fail when new observations are added that fall outside the range of environmental conditions covered by the initial data set (Frank, 1997; Leggett and Frank, 2008; Myers, 1998). As climate warming unfolds, the reduction of the ice cover is expected to ultimately impact the cryopelagic polar cod negatively (e.g. Kohlbach et al., 2017; Moline et al., 2008; Tynan and DeMaster, 1997). The question is how and when will the presently beneficial relaxation of the extreme arctic conditions start to negatively impact the reproduction of the highly specialized polar cod? In the laboratory, the eggs of polar cod develop normally in the tem- 
perature range -1.0 to $3.5^{\circ} \mathrm{C}$, but not beyond $\geq 5{ }^{\circ} \mathrm{C}$ (Drost et al., 2016; Kent et al., 2016). Age-0 polar cod grow optimally at $9.0^{\circ} \mathrm{C}$ (Laurel et al., 2017, 2016b). The winter ice cover of Canadian Arctic seas is likely to continue to form over the present century (Stroeve et al., 2012), providing the frigid conditions needed for normal egg development. As well, mean spring-summer SST in the surface are presently in the range $0-5{ }^{\circ} \mathrm{C}$ (Fig. 2), which leaves much room for positive effects from warming before the optimal developmental temperature for age- 0 polar $\operatorname{cod}\left(9^{\circ} \mathrm{C}\right)$ is exceeded. Hence, increasing SST in spring and summer may have little immediate negative effect on polar cod recruitment.

As discussed above, a progressively earlier ice breakup will improve juvenile recruitment in the fall by increasing the survival of early hatchers, at least initially. There may exist a threshold beyond which an ever-earlier ice breakup becomes detrimental to the survival of polar cod early hatchers. For instance, ice algae start growing when light levels at the ice-water interface reach $\sim 7 \mu \mathrm{E} \mathrm{m}^{-2} \mathrm{~s}^{-1}$ (Gosselin et al., 1985), typically in April at the latitudes studied here. If ice breakup eventually regresses to April, ice algal production would no longer occur for lack of an ice substrate. A reduced ice algal production might disrupt the reproduction of copepods such as Pseudocalanus spp. and Calanus glacialis (Tourangeau and Runge, 1991), the nauplii of which are the main prey of polar cod larvae at first feeding (Bouchard et al., 2016). Similarly, juvenile polar cod rely on the nauplii and copepodites of the lipid-rich Calanus glacialis and Calanus hyperboreus to sustain growth (e.g. Bouchard et al., 2016). Warmer waters could trigger a replacement of these species by smaller, relatively lipid-poor species such as the subarctic Calanus finmarchicus (Kjellerup et al., 2012; Slagstad et al., 2011). For instance, Hunt et al. (2011) report that large numbers of age-0 walleye pollock (Gadus chalcogrammus) survive to summer in years of extremely early ice breakup in the Bering Sea. However, extremely early ice breakups also reduce the production of large, lipid-rich, crustacean prey, which results in low condition of age- 0 pollock, increased vulnerability to predation as fish switch from zooplankton prey to age0 pollock, and poor recruitment to age-1. Finally, an early ice melt could shrink the habitat of some of the age- 1 and age- 2 polar cod that recruit to the ice pack of the Arctic Ocean (David et al., 2016).

However, the ongoing migration to northern waters of subarctic species in response to changing conditions (e.g. Berge et al., 2015; Fossheim et al., 2015; Kortsch et al., 2015) could eventually be the main cause of the demise of the hyper-specialized polar cod, with all the expected cascading impacts on the unique pelagic ecosystems and biodiversity of Arctic seas (e.g. Moline et al., 2008; Tynan and DeMaster, 1997). Already, indications are that generalist forage fish such as the capelin (Mallotus villous) and the sand lance (Ammodytes spp.) are outcompeting polar cod in Hudson Bay (Provencher et al., 2012). Potential predators of polar cod, such as the Atlantic cod (Gadus morhua), haddock (Melanogrammus aeglefinus) and Atlantic mackerel (Scomber scombrus), are thriving in Svalbard waters and the Greenland Sea (Berge et al., 2015), and other piscivorous species, such as redfish (Sebastes spp.), recently became ubiquitous in the area (M. Geoffroy, unpublished data). In coming decades or by mid-century, competition and predation from invading subarctic species will likely curb the ongoing positive effect of a progressively earlier ice breakup on the survival of young polar cod.

\section{Acknowledgements}

We thank the officers and crew of the CCGS Amundsen and F/V Frosti for their dedication and professionalism. We are grateful to the several technicians and colleagues who contributed to sampling and analysis over the years. Experts at the Canada Excellence Research Chair in remote sensing of Canada's new Arctic frontier provided valuable recommendations for processing MODIS data. The National Oceanic and Atmospheric Administration graciously lent the transducers used on board the Frosti, and Yvan Simard (Fisheries and Oceans Canada) lent the transceivers. Thanks to the Beaufort Region Environmental Assessment (BREA) program of Indian and Northern Affairs Canada, the Network of Centres of Excellence ArcticNet, the Canadian International Polar Year, and the Canada Foundation for Innovation (Amundsen Science) for financial support. MG and CB benefited from scholarships and fellowships awarded by the W. Garfield Weston Foundation. MG and ML received scholarships from the Natural Sciences and Engineering Research Council of Canada (NSERC). This is a contribution to Québec-Océan at Université Laval, ArcticNet, and the Canada Research Chair on the response of arctic marine ecosystems to climate warming.

\section{References}

Ardyna, M., Babin, M., Gosselin, M., Devred, E., Rainville, L., Tremblay, J.É., 2014 Recent Arctic Ocean sea ice loss triggers novel fall phytoplankton blooms. Geophys. Res. Lett. 41, 6207-6212.

Benoit, D., Simard, Y., Fortier, L., 2008. Hydroacoustic detection of large winter aggregations of Arctic cod (Boreogadus saida) at depth in ice-covered Franklin Bay (Beaufort Sea). J. Geophys. Res. C: Oceans 113, C06S90.

Benoit, D., Simard, Y., Fortier, L., 2014. Pre-winter distribution and habitat characteristics of polar cod (Boreogadus saida) in southeastern Beaufort Sea. Polar Biol. 37, 149-163.

Berge, J., Heggland, K., Lønne, O.J., Cottier, F., Hop, H., Gabrielsen, G.W., Nøttestad, L., Misund, O.A., 2015. First records of Atlantic mackerel (Scomber scombrus) from the Svalbard Archipelago, Norway, with possible explanations for the extension of its distribution. Arctic 68, 8.

Bouchard, C., Fortier, L., 2008. Effects of polynyas on the hatching season, early growth and survival of polar cod Boreogadus saida in the Laptev Sea. Mar. Ecol. Prog. Ser. 355, 247-256.

Bouchard, C., Fortier, L., 2011. Circum-arctic comparison of the hatching season of polar cod Boreogadus saida: a test of the freshwater winter refuge hypothesis. Prog. Oceanogr. 90, 105-116.

Bouchard, C., Mollard, S., Suzuki, K., Robert, D., Fortier, L., 2016. Contrasting the early life histories of sympatric Arctic gadids Boreogadus saida and Arctogadus glacialis in the Canadian Beaufort Sea. Polar Biol. 39, 1005-1022.

Bouchard, C., Robert, D., Nelson, R.J., Fortier, L., 2013. The nucleus of the lapillar otolith discriminates the early life stages of Boreogadus saida and Arctogadus glacialis. Polar Biol. 36, 1537-1542.

Browman, H.I., 2014. Commemorating 100 years since Hjort's 1914 treatise on fluctuations in the great fisheries of northern Europe: where we have been, where we are, and where we are going. ICES J. Mar. Sci. 71, 1989-1992.

Campana, S.E., Jones, C.M., 1992. Analysis of otolith microstructure data. In: Stevenson, D.K., Campana, S.E. (Eds.), Otolith Microstructure Examination and Analysis. Can Spec Publ Fish Aquat Sci 117, pp. 73-100.

Cushing, D.H., Horwood, J.W., 1994. The growth and death of fish larvae. J. Plankton Res. 16, 291-300.

David, C., Lange, B., Krumpen, T., Schaafsma, F., van Franeker, J.A., Flores, H., 2016 Under-ice distribution of polar cod Boreogadus saida in the central Arctic Ocean and their association with sea-ice habitat properties. Polar Biol. 39, 981-994.

Demer, D., Berger, L., Bernasconi, M., Bethke, E., Boswell, K., Chu, D., Domokos, R., 2015. Calibration of Acoustic Instruments. ICES Cooperative Research Report 133.

Drost, H.E., Lo, M., Carmack, E.C., Farrell, A.P., 2016. Acclimation potential of Arctic cod (Boreogadus saida) from the rapidly warming Arctic Ocean. J. Exp. Biol. 219, 3114-3125.

Daase, M., Falk-Petersen, S., Varpe, Ø., Darnis, G., Søreide, J.E., Wold, A., Leu, E., Berge J., Philippe, B., Fortier, L., 2013. Timing of reproductive events in the marine copepod Calanus glacialis: a pan-Arctic perspective. Can. J. Fish. Aquat. Sci. 70 $871-884$.

Falardeau, M., Bouchard, C., Robert, D., Fortier, L., 2017. First records of Pacific sand lance (Ammodytes hexapterus) in the Canadian Arctic Archipelago. Polar Biol. http://dx.doi.org/10.1007/s00300-017-2141-0 (in press).

Fortier, L., Ponton, D., Gilbert, M., 1995. The match/mismatch hypothesis and the feeding success of fish larvae in ice-covered southeastern Hudson Bay. Mar Ecol. Prog. Ser. 120, 11-27.

Fortier, L., Reist, J.D., Ferguson, S.H., Archambault, P., Matley, J., Macdonald, R.W. Robert, D., Darnis, G., Geoffroy, M., Suzuki, K., Falardeau, M., MacPhee, S.A., Majewsi, A.R., Marcoux, M., Sawatzky, C.D., Atchison, S., Loseto, L.L., Grant, C. Link, H., Asselin, N.C., Harwood, L.A., Slavik, D., Letcher, R.J., 2015. Arctic change: impacts on marine ecosystems and contaminants. In: Stern, G.A., Gaden, A. (Eds.), From Science to Policy in the Western and Central Canadian Arctic: An Integrated Regional Impact Study (IRIS) of Climate Change and Modernization. ArcticNet, Quebec City, pp. 200-253 (Chapter 4).

Fortier, L., Sirois, P., Michaud, J., Barber, D., 2006. Survival of Arctic cod larvae (Boreogadus saida) in relation to sea ice and temperature in the Northeast Water Polynya (Greenland Sea). Can. J. Fish. Aquat. Sci. 63, 1608-1616. 
Fossheim, M., Primicerio, R., Johannesen, E., Ingvaldsen, R.B., Aschan, M.M., Dolgov, A.V., 2015. Recent warming leads to a rapid borealization of fish communities in the Arctic. Nat. Clim. Change 5, 673-677.

Francois, R.E., Garrison, G.R., 1982. Sound absorption based on ocean measurements. Part II: boric acid contribution and equation for total absorption. J. Acoust. Soc. Am. 72, 1879-1890.

Frank, K.T., 1997. The utility of early life history studies and the challenges of recruitment prediction. In: Chambers, R.C., Trippel, E.A. (Eds.), Early Life History and Recruitment in Fish Populations. Chapman and Hall, London, UK, pp. 495512.

Galbraith, P.S., Larouche, P., 2011. Sea-surface temperature in Hudson Bay and Hudson Strait in relation to air temperature and ice cover breakup, 1985-2009. J. Mar. Syst. 87, 66-78.

Geoffroy, M., Majewski, A., LeBlanc, M., Gauthier, S., Walkusz, W., Reist, J.D., Fortier L., 2016. Vertical segregation of age -0 and age- $1+$ polar cod (Boreogadus saida) over the annual cycle in the Canadian Beaufort Sea. Polar Biol. 39, 1023-1037.

Geoffroy, M., Robert, D., Darnis, G., Fortier, L., 2011. The aggregation of polar cod (Boreogadus saida) in the deep Atlantic layer of ice-covered Amundsen Gulf (Beaufort Sea) in winter. Polar Biol. 34, 1959-1971.

Gosselin, M., Legendre, L., Demers, S., Ingram, R.G., 1985. Reponses of sea-ice microalgae to climatic and fortnightly tidal energy inputs (Manitounuk Sound, Hudson Bay). Can. J. Fish. Aquat. Sci. 42, 999-1006.

Hop, H., Falk-Petersen, S., Svendsen, H., Kwasniewski, S., Pavlov, V., Pavlova, O. Soreide, J.E., 2006. Physical and biological characteristics of the pelagic system across Fram Strait to Kongsfjorden. Prog. Oceanogr. 71, 182-231.

Houde, E.D., 2008. Emerging from Hjort's Shadow. J. Northwest Atlant. Fish. Sci. 41, 53-70.

Hunt, J.G.L., Coyle, K.O., Eisner, L.B., Farley, E.V., Heintz, R.A., Mueter, F., Napp, J.M., Overland, J.E., Ressler, P.H., Salo, S., Stabeno, P.J., 2011. Climate impacts on eastern Bering Sea foodwebs: a synthesis of new data and an assessment of the Oscillating Control Hypothesis. ICES J. Mar. Sci. 68, 1230-1243.

Ji, R., Jin, M., Varpe, Ø., 2013. Sea ice phenology and timing of primary production pulses in the Arctic Ocean. Glob. Change Biol. 19, 734-741.

Kahru, M., Brotas, V., Manzano-Sarabia, M., Mitchell, B.G., 2011. Are phytoplankton blooms occurring earlier in the Arctic? Glob. Change Biol. 17, 1733-1739.

Kent, D., Drost, H.E., Fisher, J., Oyama, T., Farrell, A.P., 2016. Laboratory rearing of wild Arctic cod Boreogadus saida from egg to adulthood. J. Fish Biol. 88, 12411248.

Kjellerup, S., Dünweber, M., Swalethorp, R., Nielsen, T.G., Møller, E.F., Markager, S., Hansen, B.W., 2012. Effects of a future warmer ocean on the coexisting copepods Calanus finmarchicus and C. glacialis in Disko Bay, western Greenland. Mar. Ecol. Prog. Ser. 447, 87-108.

Kohlbach, D., Schaafsma, F.L., Graeve, M., Lebreton, B., Lange, B.A., David, C., Vortkamp, M., Flores, H., 2017. Strong linkage of polar cod (Boreogadus saida) to sea ice algae-produced carbon: evidence from stomach content, fatty acid and stable isotope analyses. Prog. Oceanogr. 152, 62-74.

Kortsch, S., Primicerio, R., Fossheim, M., Dolgov, A.V., Aschan, M., 2015. Climate change alters the structure of arctic marine food webs due to poleward shifts of boreal generalists. Proc. R. Soc. B: Biol. Sci. 282, 20151546.

Laurel, B.J., Copeman, L.A., Spencer, M., Iseri, P., 2017. Temperature-dependent growth as a function of size and age in juvenile Arctic cod (Boreogadus saida). ICES J. Mar. Sci. http://dx.doi.org/10.1093/icesjms/fsx028.

Laurel, B.J., Knoth, B.A., Ryer, C.H., 2016a. Growth, mortality, and recruitment signals in age-0 gadids settling in coastal Gulf of Alaska. ICES J. Mar. Sci. 73, 2227-2237.

Laurel, B.J., Spencer, M., Iseri, P., Copeman, L.A., 2016b. Temperature-dependent growth and behavior of juvenile Arctic cod (Boreogadus saida) and co-occurring North Pacific gadids. Polar Biol. 39, 1127-1135.

Laxon, S.W., Giles, K.A., Ridout, A.L., Wingham, D.J., Willatt, R., Cullen, R., Kwok, R., Schweiger, A., Zhang, J., Haas, C., Hendricks, S., Krishfield, R., Kurtz, N., Farrell, S., Davidson, M., 2013. CryoSat-2 estimates of Arctic sea ice thickness and volume. Geophys. Res. Lett. 40, 732-737.

Leggett, W.C., Frank, K.T., 2008. Paradigms in fisheries oceanography. Oceanogr. Mar. Biol. Annu. Rev. 46, 331-363.

Lenoir, S., Beaugrand, G., Lecuyer, É., 2011. Modelled spatial distribution of marine fish and projected modifications in the North Atlantic Ocean. Glob. Change Biol. 17, $115-129$
Li, W.K.W., McLaughlin, F.A., Lovejoy, C., Carmack, E.C., 2009. Smallest algae thrive as the Arctic Ocean freshens. Science 326, 539.

Mackenzie, K.V., 1981. Nine-term equation for sound speed in the oceans. J. Acoust. Soc. Am. 70, 807-812.

Michaud, J., Fortier, L., Rowe, P., Ramseier, R., 1996. Feeding success and survivorship of Arctic cod larvae, Boreogadus saida, in the Northeast Water Polynya (Greenland Sea). Fish. Oceanogr. 5, 120-135.

Moline, M.A., Karnovsky, N.J., Brown, Z., Divoky, G.J., Frazer, T.K., Jacoby, C.A., Torres, J.J., Fraser, W.R., 2008. High latitude changes in ice dynamics and their impact on polar marine ecosystems. Ann. N. Y. Acad. Sci. 1134, 267-319.

Myers, R.A., 1998. When do environment-recruitment correlations work? Rev. Fish Biol. Fisheries 8, 285-305.

Parker-Stetter, S.L., Rudstam, L.G., Sullivan, P.J., Warner, D.M., Blood, S.J., 2009. Standard Operating Procedures for Fisheries Acoustic Surveys in the Great Lakes. Ann Arbor, MI, USA.

Perry, A.L., Low, P.J., Ellis, J.R., Reynolds, J.D., 2005. Climate change and distribution shifts in marine fishes. Science 308, 1912-1915.

Ponton, D., Fortier, L., 1992. Vertical distribution and foraging of marine fish larvae under the ice cover of southeastern Hudson Bay. Mar. Ecol. Prog. Ser. 81, 215227.

Provencher, J.F., Gaston, A.J., O’Hara, P.D., Gilchrist, H.G., 2012. Seabird diet indicates changing Arctic marine communities in eastern Canada. Mar. Ecol. Prog. Ser. 454, 171-182.

Renaud, P., Berge, J., Varpe, Ø., Lønne, O., Nahrgang, J., Ottesen, C., Hallanger, I., 2012. Is the poleward expansion by Atlantic cod and haddock threatening native polar cod Boreogadus saida. Polar Biol. 35, 401-412.

Ringuette, M., Fortier, L., Fortier, M., Runge, J.A., Bélanger, S., Larouche, P., Weslawski, J.-M., Kwasniewski, S., 2002. Advanced recruitment and accelerated population development in Arctic calanoid copepods of the North Water. Deep-Sea Res. Part II: Top. Stud. Oceanogr. 49, 5081-5099.

Scott, J.B., Marshall, G.J., 2010. A step-change in the date of sea-ice breakup in western Hudson Bay. Arctic, 155-164.

Simmonds, J., MacLennan, D., 2005. Fisheries Acoustics: Theory and Practice. Blackwell Publishing, Oxford.

Slagstad, D., Ellingsen, I.H., Wassmann, P., 2011. Evaluating primary and secondary production in an Arctic Ocean void of summer sea ice: an experimenta simulation approach. Prog. Oceanogr. 90, 117-131.

Sogard, S.M., 1997. Size-selective mortality in the juvenile stage of teleost fishes: a review. Bull. Mar. Sci. 60, 1129-1157.

Steele, M., Ermold, W., Zhang, J., 2008. Arctic Ocean surface warming trends over the past 100 years. Geophys. Res. Lett. 35, L19715.

Stirling, I., 2002. Polar bears and seals in the eastern Beaufort Sea and Amundsen Gulf: a synthesis of population trends and ecological relationships over three decades. Arctic 55, 59-76.

Stroeve, J.C., Serreze, M.C., Holland, M.M., Kay, J.E., Malanik, J., Barrett, A.P., 2012. The Arctic's rapidly shrinking sea ice cover: a research synthesis. Clim. Change 110, 1005-1027.

Søreide, J.E., Leu, E.V.A., Berge, J., Graeve, M., Falk-Petersen, S., 2010. Timing of blooms, algal food quality and Calanus glacialis reproduction and growth in a changing Arctic. Glob. Change Biol. 16, 3154-3163.

Tourangeau, S., Runge, J.A., 1991. Reproduction of Calanus glacialis under ice in spring in southern Hudson Bay, Canada. Mar. Biol. 108, 227-233.

Tremblay, J.-É., Gagnon, J., 2009. The effects of irradiance and nutrient supply on the productivity of Arctic waters: a perspective on climate change. In: Nihoul, J.C.J., Kostianoy, A.G. (Eds.), Influence of Climate Change on the Changing Arctic and Sub-Arctic Conditions. Springer Netherlands, Dordrecht, pp. 73-93.

Tynan, C.T., DeMaster, D.P., 1997. Observations and predictions of Arctic climatic change potential effects on marine mammals. Arctic 50, 308-322.

Varpe, Ø., Daase, M., Kristiansen, T., 2015. A fish-eye view on the new Arctic lightscape. ICES J. Mar. Sci. 72, 2532-2538.

Welch, H.E., Bergmann, M.A., Siferd, T.D., Martin, K.A., Curtis, M.F., Crawford, R.E., Conover, R.J., Hop, H., 1992. Energy flow through the marine ecosystem of the Lancaster Sound region, Arctic Canada. Arctic 45, 343-357.

Wood, K.R., Overland, J.E., Salo, S.A., Bond, N.A., Williams, W.J., Dong, X., 2013. Is there a "new normal" climate in the Beaufort Sea? Polar Res. 32, 19552. 